\title{
Comparative economical analysis regarding the technologies for the processing of the support plates Ion CIUPITU ${ }^{1, a}$, Florin STANCULEANU ${ }^{2, b}$
}

${ }^{1}$ Department of Engineering and Management of Technological Systems, Faculty of Mechanics, University of Craiova, $1^{\text {st }}$ Calugareni Street, Drobeta Turnu Severin, Mehedinti County, Romania

\author{
${ }^{2}$ Splaiul Independenței 313, București 060042, Romania \\ aion_ciupitu@yahoo.ro, bflorin_stanculeanu@yahoo.com
}

Keyword: cost calculation, laser processing, plasma cutting, punching

\begin{abstract}
Fabrication of the support plates can be done using several technologies, but an important aspect of the launching of the product on the free market is the final cost of the product. This paper aims to realize a comparative study regarding the costs of the manufacturing of the support plates. Calculation costs for few technologies as laser processing, plasma cutting and punching will be presented in order to establish the optimal cost for product. Discussions related to the economical efficiency of the technologies which can be used during the process have been performed.
\end{abstract}

\section{Introduction}

For the manufacturing of support plates it is necessary to start from the plane shape of the work piece, type of the material, conditions established through design and dimensions of the piece. The shape of the piece allows the possibility of choosing more technologies in order to process the product, as following:

- Manufacturing the piece through contour cutting and drilling through laser cutting

- Manufacturing the piece through contour cutting and drilling with plasma

- Manufacturing the piece through contour cutting and punching holes through stamping

For each technological method, taken into consideration, must be studied the acquisition and the depreciation costs of the tools, the productivity of the processing as function of the different cutting regimes and the qualification of the workers. To solve the problem, it is necessary to study the volume of the production. These technological methods require complex devices and exploitation costs. The complexity of the equipments needs special attention regarding the electrical energy quality and additional devices required for optimal functioning of the process.

Industrial processing of the plates uses plasma or laser cutting for large plates from different materials (steel, copper, aluminum) but the costs of the acquisition and maintenance of these devices used in processing are higher. On the other hand, the precision required by special applications can be specific criteria for choosing the right technology for obtaining the support plates.

\section{Calculation of the costs}

The costs incurred for fabrication of the support plates can be calculated using some fundamentals expressions taking into account the factors which composed the total cost of the manufacturing the products. All these factors are presented in the next formula:

$$
C=C_{m}+C_{s c}+C_{o}+C_{d t}+C_{t d v}
$$

where:

- $\mathrm{C}-$ total costs inquired for the fabrication of the product; 
- $\mathrm{C}_{\mathrm{m}}$ - costs of the materials: it means the taking into account specific factors as the planar surface area, thickness of the material, specific weight of the material, specific coefficient related to the utilization of the material and cost per unit of the material;

- $\mathrm{C}_{\mathrm{sc}}$ - costs with staff meaning net salary and other legal charges (social charges, state budget, etc.), average time per operation for the production of a single unit, average time for preparing the devices for a proper functioning and the number of products

- $\mathrm{C}_{\mathrm{o}}$ - costs with overheads: it means the taking into account the costs related to the consumption of the electrical energy, water, technical gases and other specific conditions required by the process; all these factors can be summarized as $2-2,5 \%$ from staff costs

- $\mathrm{C}_{\mathrm{dt}}-$ costs with the depreciation of the tools and devices used in fabrication and it means the taking into account the initial value of the devices, the annual programme of manufacturing, the regulations related to the depreciation cost of the devices and the level of the working time of the equipments

- $\mathrm{C}_{\mathrm{tdv}}$ - costs with depreciation of the tools and devices used in checking process; represent the same costs as depreciation cost which has been presented above, but this cost is applied to the verification tools; this cost is composed from some factors as the annual programme of fabrication, the initial cost of the verification tools and the number of the units produced during a year

The costs incurred during the fabrication process of the support plates, using the three technologies, previously presented in the paper, can be summarize in the table 1 presented below. These costs does not include the profit and additional costs related to the deployment of the product on market.

Table 1 Costs incurred for manufacturing of the product

\begin{tabular}{|l|c|c|c|}
\hline \multicolumn{1}{|c|}{ Category of costs } & $\begin{array}{c}\text { Costs for } \\
\text { laser processing } \\
\text { [EUR] }\end{array}$ & $\begin{array}{c}\text { Cost for } \\
\text { plasma cutting } \\
\text { [EUR] }\end{array}$ & $\begin{array}{c}\text { Cost for } \\
\text { punch processing } \\
\text { [EUR] }\end{array}$ \\
\hline Costs with materials & 0.35 & 0.35 & 0.35 \\
\hline Costs with salary & 0.25 & 0.37 & 0.02 \\
\hline Costs with overheads & 0.58 & 0.86 & 0.06 \\
\hline $\begin{array}{l}\text { Costs with depreciation } \\
\text { of tools and devices used } \\
\text { in fabrication process }\end{array}$ & 0.77 & 0.56 & 0.26 \\
\hline $\begin{array}{l}\text { Costs with depreciation } \\
\text { of the tools and devices } \\
\text { used in checking process }\end{array}$ & 0.08 & 0.08 & 0.13 \\
\hline \multicolumn{1}{|c|}{ Total } & 2.03 & 2.22 & 0.82 \\
\hline
\end{tabular}

\section{Results and discussions}

After the calculation of the costs for all three technologies presented above, it can be observed that the punching technology is the best solution for obtaining the support plates. Further calculation regarding the final price of the product will be performed. Thus, in the table below, will be presented the results obtained during the calculation process.

The final cost obtained for the fabricated product can be calculated using the formula presented below:

$$
P_{v}=C+P+S
$$

where:

- $\mathrm{P}_{\mathrm{v}}$ - sale price of the product 
- $\mathrm{C}$ - costs related to the fabrication of the product

- $\mathrm{P}$ - the profit of the manufacturer

- $\mathrm{S}-$ cost of sales of the product on a competitive market

Table 2 Calculation of the final prices

\begin{tabular}{|l|c|}
\hline \multicolumn{1}{|c|}{ Technology } & $\begin{array}{c}\text { Price with VAT } \\
\text { [EUR] }\end{array}$ \\
\hline Laser processing & 2.51 \\
\hline Plasma cutting & 3.31 \\
\hline Punching & 1.25 \\
\hline
\end{tabular}

From table 2 it can be observed that the total cost for the manufacturing of the support plates, using punching process, is smaller than other processes. That cost is explained mainly by the complexity of the equipments used for plasma or laser processing. The economical efficiency can be calculated using the higher and the lower price obtained for the technologies used into the fabrication process.

$$
E_{f}=P_{H}-P_{L}
$$

where:

- $\mathrm{E}_{\mathrm{f}}$ - economical efficiency

- $\mathrm{P}_{\mathrm{H}}$ - the highest price calculated for all three technologies

- $\mathrm{P}_{\mathrm{L}}$ - the lowest price calculated for all three technologies

$$
E_{f}=3.31-1.25=2.06 \text { eur/unit }
$$

\section{Conclusions}

The support plates can be manufactured using several technologies as following: laser processing, plasma cutting or mechanical punching.

Calculation costs performed has shown that the punching technology is the best technology from economical point of view.

The laser processing and plasma cutting offer better precision than punching process but these two processes are more expensive than punching. That statement can be taken into account for small and high production as well.

In some cases, other technologies can be used. If the execution draw is too complex, the utilization of plasma cutting process or laser processing can be a better solution. This statement is sustained by the cost incurred by the designing of the new punching tool. Taking into account that the plasma or laser cutting device is controlled by process computer, product with higher complexity can be fabricated using proper software.

The punching process requires small resources but is limited to defined shapes of the products. On the other hand, the technologies as plasma cutting or laser processing need higher investments, higher energy consumption, more qualified personnel for operation and maintenance, but with better versatility.

\section{References}

[1] M. Teodorescu, Gh. Zgura, Elemente de proiectare a ştanţelor şi matriţelor.

[2] G. S. Georgescu, Îndrumător pentru ateliere mecanice.

[3] C. Picoş, Calculul adaosurilor de prelucrare şi al regimurilor de aşchiere.

[4] C. Picoş, Normarea tehnica, Vol. I, Vol. II. 
[5] Ciupitu, I., et al. - The improving of the process of the iron, the cast iron and the copper powder mixing, Materials Science Forum Vol. 672 (2011), pag. 76-79, edited by Trans. Tech. Publications Ltd, Switzerland, ISSN: 1662-9752, DOI: 10.4028/www.scientific.net/MSF.672.76 .

[6] Vlase, Regimuri de aşchiere, adaosuri de prelucrare şi norme tehnice de timp, vol. I, vol. II.

[7] I.D. Savu, S.V. Savu, G. Sebeș, Preheating and heat addition by laser beam in hybrid laser-US welding, J Therm Anal Calorim (2013), 111:1221-1226, DOI: 10.1007/s10973-012-2449-5.

[8] Subbarao Chamarthi, N. Sinivasa Reddy, Manoj Kumar Elipey, D.V. Ramana Reddy, Investigation Analysis of Plasma Arc Cutting Parameters on the Unevenness Surface of Hardox-400 Material, International Conference on Design and Manufacturing (IConDM2013), 2013, vol. 64, p. 854-861.

[9] I. D. Savu, S. V. Savu, N. A. Sirbu, Sorin Savu, Heat affected zones in polymer laser marking, Journal of Thermal Analysis and Calorimetry, pag. 1-11, 2013, DOI: 10.1007/s10973-013-3443-2. 